\title{
Postup při řešení střetu motocyklu se silničním motorovým vozidlem
}

\section{Solution Process of Collision Motorcycle with Road Motor Vehicle}

\author{
Petr Slepánek* \\ Vysoké učeni technické v Brně, Ústav soudního inženýrství, Brno
}

\begin{abstract}
Abstrakt
Článek popisuje vhodnou metodiku pro analýzy střetu mezi motocyklem a silničním motorovým vozidlem. Je zde navržena vhodná kategorizace dopravních nehod za účasti motocyklů a metodika pro řešení jednotlivých typů střetů motocyklů se silničními motorovými vozidly. Další přínos článku představují také vývojové diagramy, nabízející komplexní postup při řešení jednotlivých typů střetů motocyklu se silničním motorovým vozidlem.
\end{abstract}

Klíčová slova: střet motocyklu, střet silničního motorového vozidla, dopravní nehoda.

\section{1. ÚVOD}

Analýza nehodového děje je velmi složitý proces, při kterém je nutné používat současné metody a postupy. V současné době se pro analýzu nehodového děje používají simulační programy, avšak i zde je za správnost výsledků stále odpovědný sám znalec. Přesnost výsledků je závislá na vhodně zvolené metodě řešení a co nejpřesněji zadaných vstupních parametrech, které musí být v technicky přijatelných mezích. Problém představuje stále zcela nedostatečný a nekomplexní př́istup $\mathrm{k}$ řešení dopravních nehod za účasti motocyklů, kdy by bylo potřeba zavést konkrétní metody a postupy pro řešení jednotlivých typů nehod. Tento článek si proto klade za cíl tuto mezeru v současném stavu poznání vyplnit a navrhnout postup pro vyhodnocování různých typů dopravních nehod motocyklu se silničním motorovým vozidlem (dále jen „vozidlo").

Pro analýzu silničních nehod bylo vypracováno velké množství odborné literatury, v roce 1999 byla vydána publikace Bradáč, A. a kol.: Soudní inženýrství, Brno 1999 [1], kde je velmi přehledně a podrobně popsána analýza silničních nehod. Jako další bych

\begin{abstract}
The article describes a suitable methodology for analysis of the collision between the motorcycle and the vehicle. There is a proposal of an appropriate categorization of traffic accidents involving motorcycles, and a methodology for solving individual types of motorcycle collisions with vehicles. Other actual contributions of the article are represented also by flowcharts, offering a comprehensive approach to solving individual types of colissions of motorcycles with other vehicles.
\end{abstract}

Keywords: motorcycle collision, road motor vehicle collision, traffic accident.

uvedl studie Semela, M.: Analýza silničních nehod I, 2012 [2], Semela, M.: Analýza silničních nehod II, 2012 [3], Rábek, V.: Vybrané postupy analýzy dopravních nehod, 2009 [4], atd. Ze zahraniční literatury bych rád zmínil publikaci Kasanický, G., Kohút, P.: Analýza nehôd jednostopových vozidel, Žilina 2000 [5], Hugemann, W.: Unfall rekonstruktion, 2007 [6], Burg, H., Moser, A.: Handbook of accident reconstruction, 2014 [7], apod.

$\mathrm{Na}$ základě různých střetových poloh je v článku zavedena kategorizace dopravních nehod. Dále jsou v práci zpracovány současné metody a postupy pro řešení jednotlivých typů dopravních nehod mezi vozidly a motocykly. Uvedené vývojové diagramy mohou sloužit jako podklady pro řešení různých typů dopravních nehod za účasti motocyklů.

\section{SOUČASNÉ METODY PRO ŘEŠENÍ DOPRAVNÍCH NEHOD}

Mezi základní metody řešení dopravních nehod v současné době patř́: 

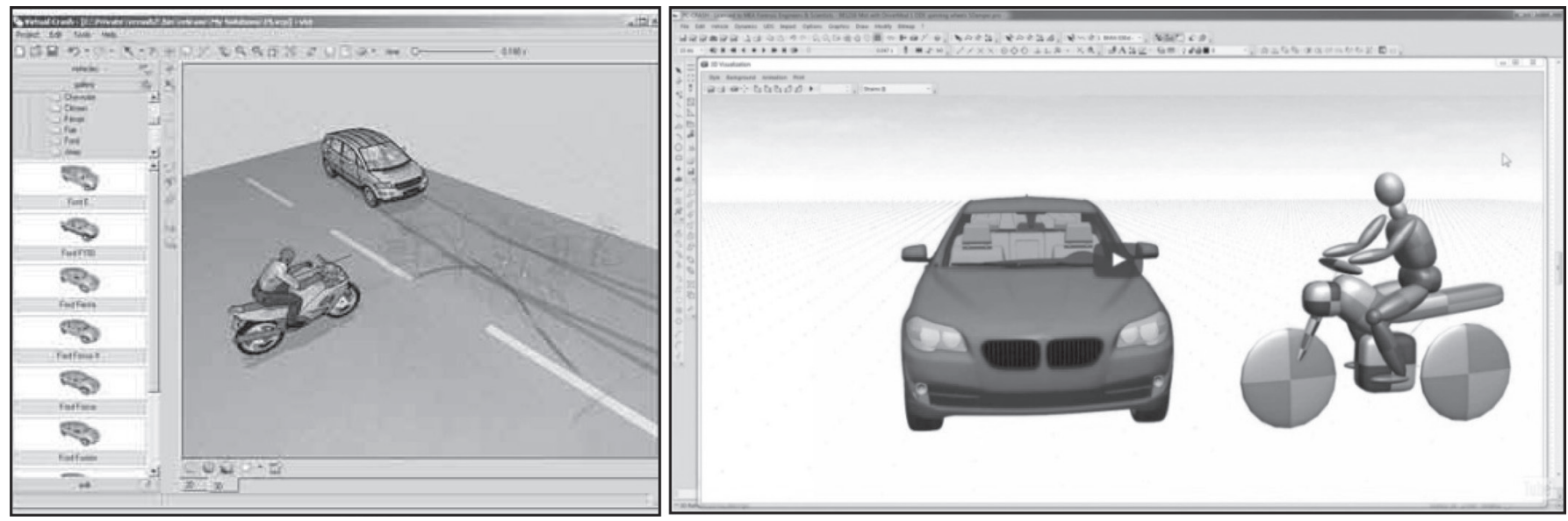

Obr. 1 Virtual CRASH verze 3.0 [8], PC-Crash verze 10.2 [9].

Fig. 1 Virtual CRASH version 3.0 [8], PC-Crash version 10.2 [9].

- metody zpětného výpočtu,

- metody dopředného výpočtu.

\subsection{Metody zpětného výpočtu - početní metody}

V některých prŕpadech je možno vypočítat rychlost jednostopého vozidla, resp. vozidla, zpětným výpočtem. $V$ takovém případě se výpočet začíná $\mathrm{v}$ konečné poloze vozidel a postupně se počítá rychlost vozidel až po okamžik vzniku kolize, príípadně jiného, pro posouzení příčin dopravní nehody důležitého, okamžiku.

\subsection{Metody zpětného výpočtu - početně-grafické metody}

Jedná se o postup od konce nehodového děje po jeho začátek. $\mathrm{Na}$ základě zdokumentovaných konečných poloh vozidel po nehodě, zanechaných stop na vozovce, atd. lze zpětným odvíjením děje vypočítat neznámé vstupní parametry (postřetové rychlosti a následně předstřetové rychlosti jednotlivých vozidel). Tato metoda je převážně ruční, řešená analytickými výpočty nebo s pomocí tabulkového procesoru.

Mezi metody zpětného výpočtu patř́:

- diagram rovnováhy hybností a impulsů (DRHI),

- modifikovaný diagram rovnováhy hybností a impulsů (MDRHI),

- metoda rhomboidního řezu (DRRHI-diagram rovnováhy rotačních hybností a impulsů),

- metoda energetického prstence,

- metoda zákonu zachování hybnosti a zákonu zachování energie metoda (ZZH+ZZE).

\subsection{Metody dopředného výpočtu}

Oproti metodám zpětného výpočtu postupují od začátku nehodového děje po jeho konec s využitím matematických modelů střetu a pohybu vozidel. Tyto metody jsou realizovány s podporou simulačních programů. Ty umožňují velmi rychlou změnu vstupních parametrů při současné kontrole parametrů výstupních.

Mezi nejpoužívanější simulační programy patří zejména:

- Virtual CRASH,

- PC-Crash,

- CARAT (Computer Aided Reconstruction of Accidents in Traffic),

- Analyzer Pro, atd.
$\mathrm{K}$ řešení samotného střetu nebo výběhových parametrů lze použít program Impuls Expert. Zpočátku se použivaly i tabulkové procesory, zejména MS-Excel.

Pro dopředné řešení střetu využívají simulační programy impulsně rázový model, který modeluje silové působení pomocí impulsu síly. Tento model využívá následující zjednodušení. První zjednodušení je prostorové, při kterém je silové působení nahrazeno jedinou výslednicí, která vychází z bodu rázu. Druhé zjednodušení je časové, kdy model neuvažuje dobu, po kterou ráz probíhá a změna parametrů je okamžitá.

Metody dopředného výpočtu jsou výrazně komplexnější než metody zpětného výpočtu. Pomocí simulačních programů je možné řešit i velmi složité několikanásobné střety, komplikované složené pohyby, převracení, optimalizaci střetu, simulaci pohybu posádky apod. Lze použít rozdělení brzdné síly, použití ABS, nastavení tlumení a pružení atd. Další velkou výhodou je možnost použití vícetělesového (multibody) systému, který umožní modelaci těla (řidiče, motocyklisty atd.).

\section{KATEGORIZACE DOPRAVNÍCH NEHOD MEZI VOZIDLEM A MOTOCYKLEM}

\subsection{Typ A - střet motocyklu s protijedoucím vozidlem}

Jedná se o př́pad, kdy dochází k čelnímu střetu motocyklu $\mathrm{s}$ vozidlem, úhly podélných os jsou zpravidla blízké $180^{\circ}$. Může se jednat např́klad o situaci znázorněnou na obr. 2, kde vozidlo předjíždí jiné vozidlo nebo objíždí překážku silničního provozu a nestihne se zařadit zpět do jízdního pruhu, následně dojde ke střetu s protijedoucím motocyklem (obr. 2).

\subsection{Typ B - střet motocyklu s vozidlem křižujícím hlavní silnici}

K tomuto typu střetu dochází nejčastěji na křižovatkách, kdy jeden z účastníků jede po hlavní silnici a druhý po vedlejší. Dochází k bočním střetům, kdy úhel podélných os mezi vozidly svírá zpravidla pravý úhel, nebo podobný (nejčastěji v rozmezí 45 až $135^{\circ}$ ). Na obr. 3 je situace, kdy vozidlo jedoucí po vedlejší silnici nedá přednost zprava jedoucímu motocyklu po hlavní silnici, může se jednat i o nedání přednosti zprava (obr. 3). 


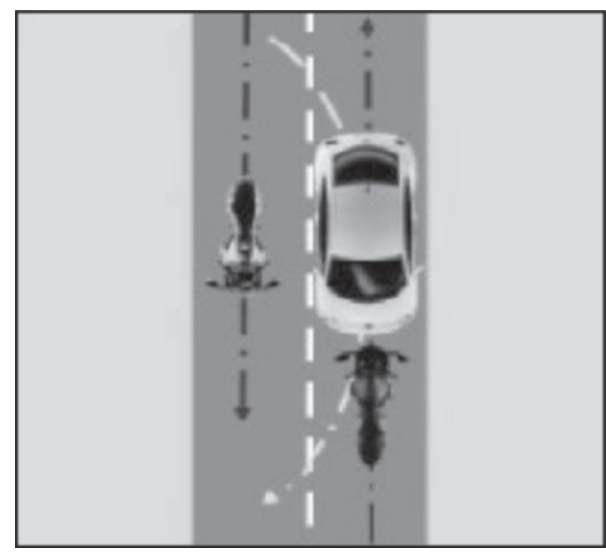

Obr. 2 Střet motocyklu s protijedoucim vozidlem.

Fig. 2 Collision of a motorcycle with an oncoming vehicle.

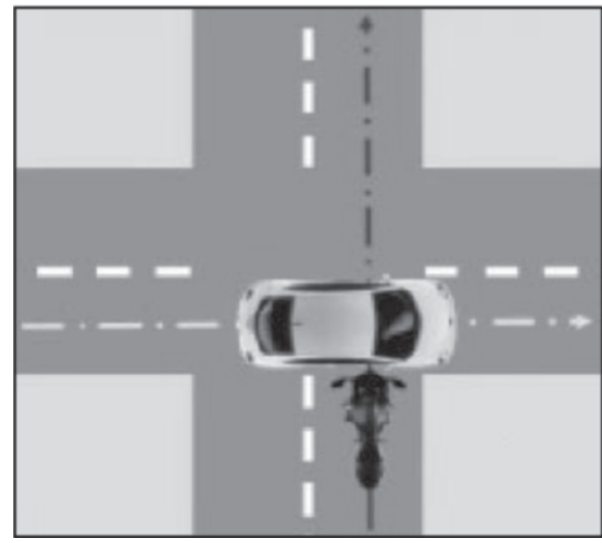

Obr. 3 Střet motocyklu s vozidlem křižujícím hlavni silnici.

Fig. 3 Collision of a motorcycle with a vehicle crossing main road.

\subsection{Typ C - střet motocyklu s vozidlem odbočujícím vlevo $z$ vedlejší silnice}

Nejčastějším místem jsou opět křižovatky. Dochází k bočním střetům, úhel podélných os mezi vozidly bývá nejčastěji v rozmezí 45 až $90^{\circ}$, podle střetové polohy a charakteru křižovatky. V tomto prrípadě vozidlo vyjíždí z vedlejší silnice, při odbočování vlevo na hlavní silnici dojde ke střetu s motocyklem, kterému vozidlo nedalo přednost (obr. 4).

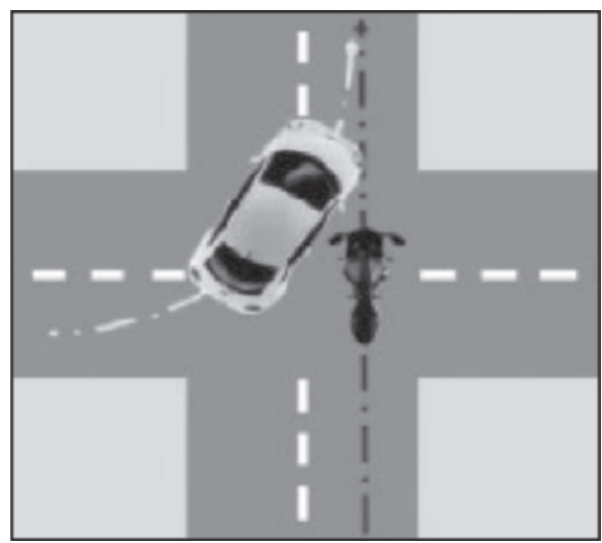

Obr. 4 Střet motocyklu s vozidlem odbočujicím vlevo z vedlejší silnice. Fig. 4 Collision of a motorcycle with a vehicle turning to the left of the side road.

\subsection{Typ D - střet motocyklu s protijedoucím vozidlem odbočujícím vlevo}

Dochází $\mathrm{k}$ bočním střetům, úhel podélných os mezi vozidly bývá nejčastěji v rozmezí 90 až $135^{\circ}$, podle střetové polohy a charakteru křižovatky. Vozidlo i motocykl jedou po hlavní silnici, vozidlo odbočuje vlevo a křižuje koridor motocyklisty (obr. 5).

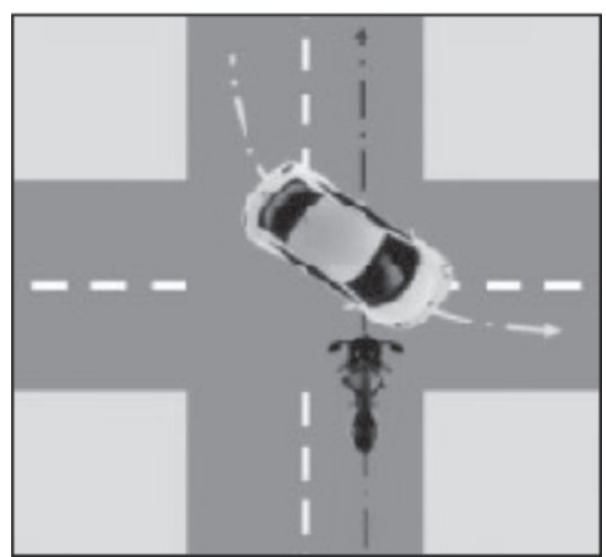

Obr. 5 Střet motocyklu s protijedoucím vozidlem odbočujicím vlevo. Fig. 5 Collision of a motorcycle with an oncoming vehicle turning left.

3.5 Typ E - střet předjíždějícího motocyklu s vozidlem, které odbočuje vlevo (vozidlo jede stejným směrem)

Vozidlo jedoucí po hlavní silnici odbočuje vlevo a je současně předjížděno motocyklem zleva. Dochází $\mathrm{k}$ bočním střetům, úhel podélných os mezi vozidly bývá nejčastěji přibližně $45^{\circ}$ (obr. 6).

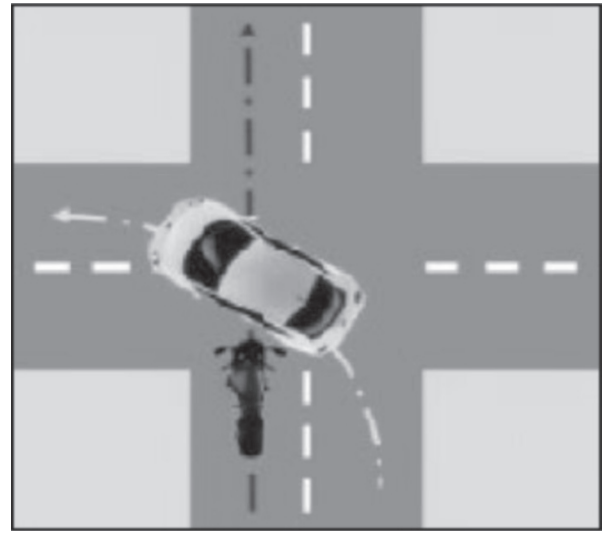

Obr. 6 Střet předjiždějicího motocyklu s vozidlem, které odbočuje vlevo. Fig. 6 Collision of an overtaking motorcycle with a vehicle that turns left.

\subsection{Typ F - střet motocyklu s vozidlem jedoucím stejným směrem (nedobrzdění)}

Tato situace nastává v okamžiku, kdy motocyklista nestihne zareagovat na brzdící vozidlo jedoucí před ním. Dochází k zadnímu střetu motocyklu do vozidla, úhly podélných os bývají téměř rovnoběžné, střetový úhel blízký $0^{\circ}$. K těmto střetům dochází nejčastěji v blízkosti křižovatek, přechodů pro chodce, světelného signalizačního zařízení (SSZ). Pro tento případ je typické nedobrzdění zadního vozidla a následným střetem do předního vozidla (obr. 7). 




Obr. 7 Střet motocyklu s vozidlem jedoucím stejným směrem. Fig. 7 Collision of a motorcycle with a vehicle running in the same direction.

\section{POSTUPY PRO ŘEŠENÍ JEDNOTLIVÝCH TYPŮ DOPRAVNÍCH NEHOD}

\subsection{Postup řešení čelních a zadních střetů - typ A, F}

Při těchto typech nehod dochází k čelním a zadním střetům, kdy podélné osy vozidel jsou téměř rovnoběžné (úhly podélných os svírají úhel $0^{\circ}$ pro zadní strety a $180^{\circ}$ pro čelní střety nebo jim blízký).

$\mathrm{K}$ čelním střetům nejčastěji dochází při předjíždění, výjezdu motocyklu ze zatáčky apod. Typickým př́kladem je střet vozidla, které předjíždí pomaleji jedoucí vozidlo a kvůli špatnému odhadu rychlosti přibližujícího se motocyklu z protisměru a také $\mathrm{v}$ důsledku jeho špatné viditelnosti dochází k čelnímu střetu vozidla s motocyklem.

Důvodem většiny zadních střetů je nedobrzdění naprríklad v kolonách, na křižovatkách, na světelně řízených křižovatkách, přechodech, apod. Řidič vozidla zastaví např́iklad u přechodu pro chodce a řidič motocyklu jedoucí stejným směrem vzhledem k nedodržení bezpečné vzdálenosti a pozdní reakci nestihne dobrzdit a naráží do tohoto vozidla obr. 8).

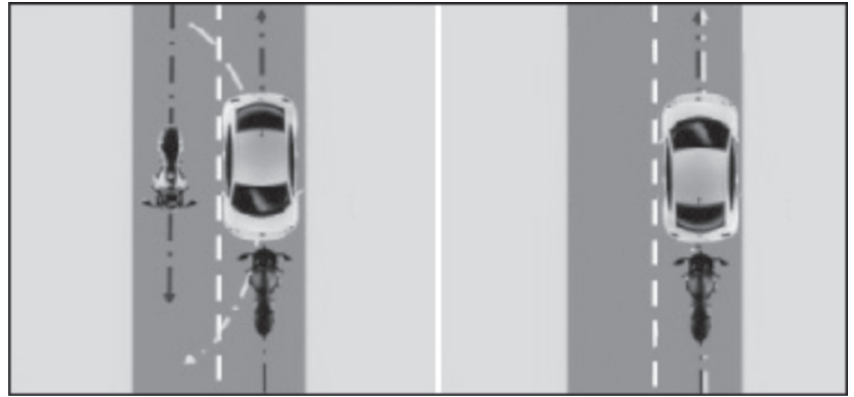

Obr. 8 Střetové konfigurace - typ A, F.

Fig. 8 Crash configurations - Type A, F.

Postup řešení těchto typů dopravních nehod je znázorněn ve vývojovém diagramu viz obr. 10.

\subsubsection{Postřet}

Pro výpočet postřetové rychlosti je třeba přesně znát postřetový pohyb obou vozidel, př́padně posádky motocyklu.
Velmi důležité jsou konečné polohy obou vozidel, stopy zanechané na vozovce a okolí po střetu.

Pohyb po střetu se většinou skládá z více fází (jízdní stopy, brzdné stopy, blokovací stopy, smykové stopy, dřecí stopy, ostatní stopy, stopy s ABS). Jednotlivým fázím postřetového pohybu náleži různé hodnoty zpomalení v rozmezí odpovídajícím charakteru a stavu povrchu (např. součinitel adheze pneumatiky na vozovce), popř́padě součinitelům tření (např̀. dření mezi kovem a asfaltem).

Je velmi důležité počítat se skutečností, že motocykl a motocyklista většinou po střetu netvoří jeden celek. Motocykl po střetu většinou zanechává po pádu na vozovku dřecí stopy od stupaček, řídítek atd. Vozidlo zanechává brzdné nebo smykové stopy.

\subsubsection{Střet}

Pokud již známe na základě výše uvedených vstupních parametrů postřetové rychlosti vozidel a jejich směry pohybů, můžeme přistoupit k řešení samotného střetu. Tato fáze je určena pro výpočet předstřetových rychlostí, které jsou pro posouzení dopravní nehody velmi důležité. Zpravidla se jedná o jednu z nejčastěji pokládaných otázek ve znaleckém posudku - jaká byla střetová rychlost vozidla, prŕípadě motocyklu v okamžiku střetu.

Pro postup řešení střetu u střetových konfigurací typu A, F, kde úhly podélných os jsou téměř rovnoběžné (úhly podélných os svírají úhel $0^{\circ}$ pro zadní střety a $180^{\circ}$ pro čelní střety nebo jim blízký), je možno použít metodu zákona zachování hybnosti a zákona zachování energie (ZZH a ZZE) a metodu průniku pásem. Ta kromě hybnostního řešení zohledňuje i energetický rozsah poškození jednotlivých vozidel.

\subsubsection{Předstřet}

Pokud známe střetové parametry a jejich předpokládané trajektorie před střetem, můžeme přistoupit $\mathrm{k}$ řešení pohybu vozidel před střetem. Pro výpočet předstřetových rychlostí je třeba přesně znát předstřetový pohyb obou vozidel, př́padně posádky motocyklu.

Vycházíme ze stop zanechaných na vozovce, poškození okolí, polohy místa potencionální reakce, atd. Pokud vozidlo před střetem nejelo konstantní rychlostí (bez reakce na vzniklou situaci), je nutné znát hodnoty zpomalení. Pro případ rozjezdu vozidla nebo motocyklu např. z křrižovatky případně jejich zrychlení.

$\mathrm{V}$ případě, že vozidlo či motocykl před střetem brzdilo, je nezbytné znát náběh brzdného účinku a reakční dobu.

Je velmi důležité počítat se skutečností, že motocykl a motocyklista nemusí v př́padě předstřetového pádu tvořit jeden celek. Motocykl po střetu většinou nechává po pádu na vozovku dřecí stopy od stupaček, řídítek atd.

Zkušený řidič je schopný i v kolizních situacích účinně používat obě brzdy (přední i zadní), zatímco nezkušený řidič zpravidla použije pouze zadní brzdu, a proto je nutné brát v úvahu zkušenosti řidiče motocyklu.

Na základě tvaru brzdné stopy můžeme v některých př́padech zjistit, kterou brzdou byla daná stopa vytvořena. Pokud je stopa dlouhá, tvaru plynulého $\mathrm{S}$, potom je s největší pravděpodobností vytvořena použitím pouze zadní brzdy. Naopak krátká brzdná stopa je s největší pravděpodobností vytvořená použitím pouze přední brzdy, přičemž na konci brzdné stopy dojde většinou ke ztrátě stability motocyklu. Při použití obou brzd má stopa většinou přímý tvar.

Brzdění motocyklů je oproti brzdění osobních vozidel rozdílné. U většiny motocyklů se ovládá př̀ední a zadní brzda vzájemně 




Obr. 9 Střetové konfigurace - typ B, C, D, E.

Fig. 9 Crash configurations - Type B, C, D, E.

nezávisle, kdežto u vozidel je pouze jeden pedál, který brzdí všechna kola. Výjimku tvoří motocykly vybavené dual brzdným systémem.

\subsection{Postup řešení bočních střetů - typ $B, C, D, E$}

Nejčastěji dochází $\mathrm{k}$ těmto střetům na křižovatkách, kdy jeden z účastníků jede po hlavní silnici a druhý po vedlejší. U těchto typů dochází nejčastěji $\mathrm{k}$ bočním střetům, kdy úhel podélných os mezi vozidly svírá zpravidla pravý úhel nebo podobný (nejčastěji v rozmezí 45 až $135^{\circ}$ viz obr. 9).

Střety při nedání přednosti v jízdě a střety odbočovací mají hodně společného, co se vypracování znaleckých posudků týče, také jejich zpracování podléhá podobnému postupu.

Střety při nedání přednosti $\mathrm{v}$ jízdě jsou typické u úrovňových křižovatek, kdy je přednost $\mathrm{v}$ jízdě upravena svislým dopravním značení (křížení hlavní a vedlejší silnice) a na kruhových objezdech. Patří mezi nejčastější typy střetů mezi vozidlem a motocyklem. Střetová poloha bývá zpravidla kolmá nebo jí blízká. Většina střetů vzniká tak, že se motocykl jedoucí po hlavní silnici střetne s vozidlem rozjíždějícím se $\mathrm{z}$ vedlejší silnice nebo naopak.

Podstatnou roli zde hraje zpravidla vysoká rychlost motocyklisty a nesprávné vyhodnocení situace řidiče vozidla. Velmi důležité je zde posouzení trajektorie drah obou účastníků, zrychlování při rozjezdu z křižovatky, dosahované brzdné pomalení před střetem, výhledové poměry, apod.

Střety odbočovací lze rozdělit na dvě podskupiny - předjížděni vozidla odbočujícího vlevo (vozidla jedoucí za sebou) a střet s protijedoucím vozidlem při odbočování vlevo.

Pro první případ je typická situace, kdy řidič vozidla jedoucího po hlavní silnici hodlá odbočit vlevo a současně je předjížděn motocyklem nebo naopak.

Klasickým druhým př́ípadem je střet vozidla jedoucího po hlavní s úmyslem odbočit vlevo, které se následně střetne s protijedoucím motocyklem nebo naopak.

Pro první případ je důležité posoudit, jestli začalo dříve předjíždění nebo odbočování. Pro druhý případ je opět důležité posouzení trajektorií obou účastníků včetně posouzení první možné reakce a dalších rozhodných okamžiků celého nehodového děje.

Postup řešení těchto typů dopravních nehod je znázorněn ve vývojovém diagramu viz obr. 11.

\subsubsection{Postřet}

Po střetu zpravidla dochází k odpoutání posádky od motocyklu. $\mathrm{V}$ př́ípadě posádky motocyklu dochází $\mathrm{k}$ letu, dopadu a sunutí do konečné polohy. U motocyklu po pádu následuje rovněž sunutí do konečné polohy.
Pro výpočet postřetové rychlosti je třeba přesně znát postřetový pohyb obou vozidel, případně posádky motocyklu.

Postup řešení je podobný jako u typu A, F.

\subsubsection{Střet}

Pokud známe velikosti postřetových rychlostí a směry hybností vozidel po střetu, můžeme začít řešit samotný střet. Pro postup řešení střetu u střetových konfigurací typu B, C, D, E, kde úhly podélných os jsou rozdílné (nejčastěji 45 až $135^{\circ}$ ), je možno použít modifikovaný diagram rovnováhy hybností a impulsů (MDRHI). Ten vychází ze změny hybnosti vozidel během střetu způsobené impulsem rázové síly. Při střetu dochází ke skokové změně rychlostí a změně směru.

\subsubsection{Přredstřet}

Předstřetová fáze se většinou skládá $\mathrm{z}$ běžné jízdy. V případě zpozorování nebezpečného objektu následuje reakční doba. Ta zahrnuje optickou reakci (zpozorování objektu), dále psychickou reakci (vyhodnocení) a svalovou reakci (např. přesun nohy z plynového na brzdový pedál). Od prvního kontaktu nohy, nebo v prrípadě přední brzdy motocyklu ruky, začíná náběh plného brzdného účinku, poté je vozidlo nebo motocykl schopen brzdit plným brzdným účinkem, podle velikosti ovládací síly na pedál nebo páku brzdy.

Rovněž zde může být i rozjezd vozidla nebo motocyklu z křižovatky, zde je pak důležitá hodnota dosahovaného zrychlení. Případně maximální rychlost průjezdu zatáčkou o daném poloměru. Součástí předstřetového pohybu může být i vyhýbací manévr.

Pro výpočet předstřetové rychlosti je třeba znát přesný předstřetový pohyb obou vozidel, a v př́ípadě předstřetového pádu motocyklu i posádky motocyklu.

Postup řešení je podobný jako u typu A, F.

\section{VÝVOJOVÉ DIAGRAMY}

Na obr. 10 je uveden vývojový diagram pro analýzu silniční nehody motocyklu s vozidlem - čelní a zadní střety.

$\mathrm{Na}$ obr. 11 je uveden vývojový diagram pro analýzu silniční nehody motocyklu s vozidlem - boční střety.

\section{ZÁVĚR}

Článek popisuje postup řešení střetu mezi vozidlem a motocyklem. Stav metodologie řešení střetu motocyklu s vozidlem je v současné 




Obr. 10 Vývojový diagram - typ A, F.

Fig. 10 Flowchart-type A, F. 




Obr. 10 Vývojový diagram - typ A, F (pokračování).

Fig. 10 Flowchart-type A, F (continuation). 


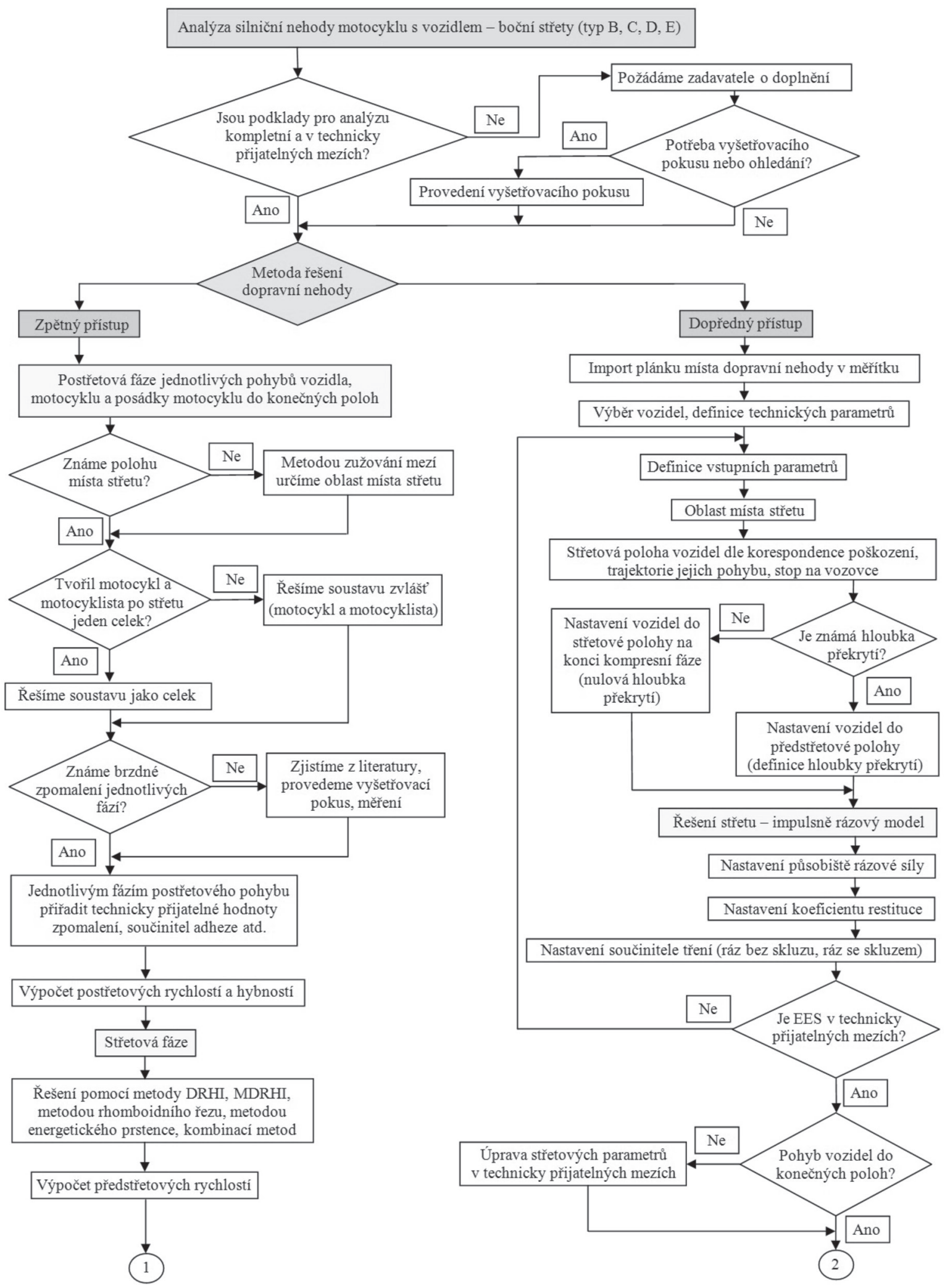

Obr. 11 Vývojový diagram - typ $B, C, D, E$.

Fig. 11 Flowchart-type B, C, D, E. 


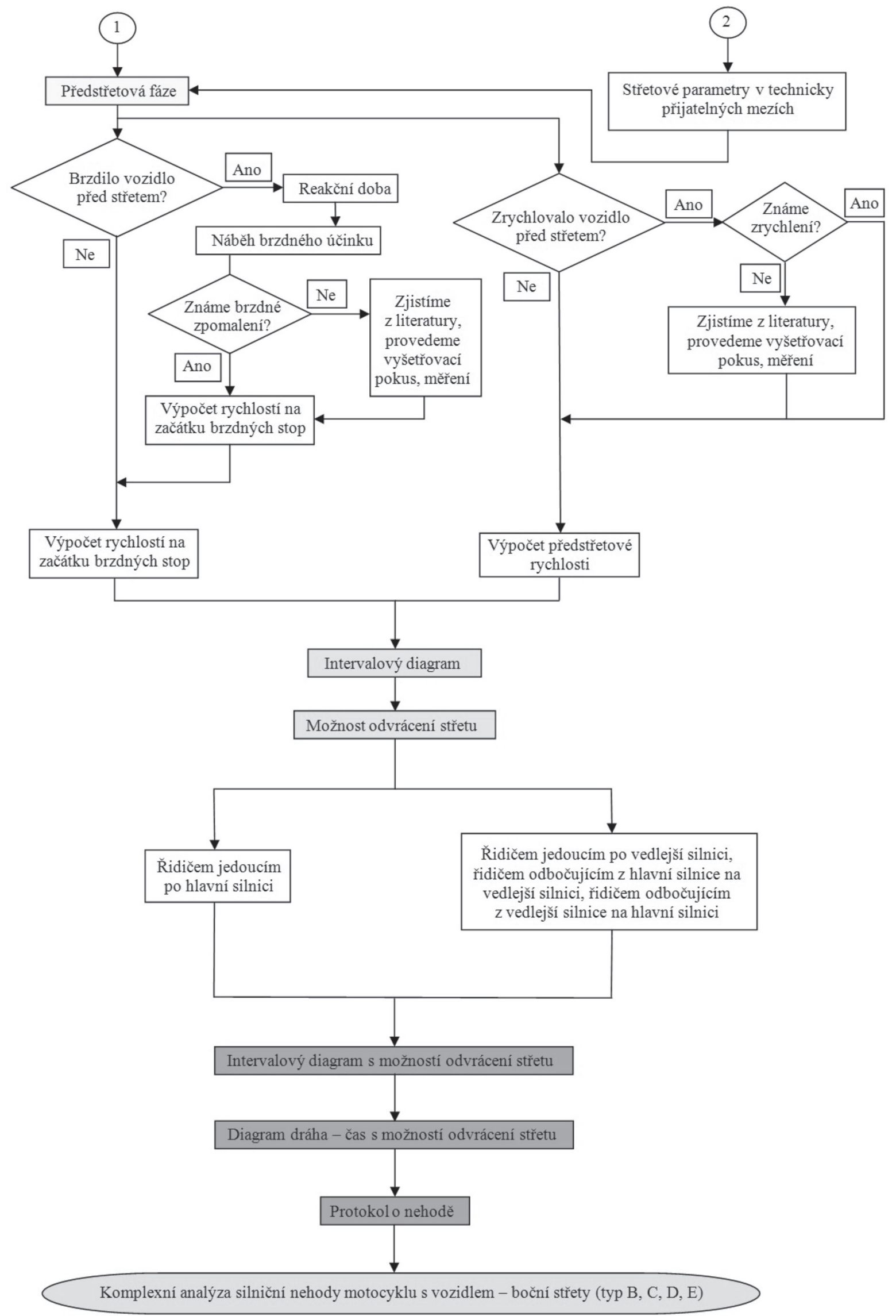

Obr. 11 Vývojový diagram-typ $B, C, D, E$ (pokračování).

Fig. 11 Flowchart-type B, C, D, E (continuation). 
době nedostačující, nebot' jednotlivé metody používané pro vyhodnocování dopravních nehod nejsou vhodné pro jednotlivé typy střetu motocyklů s vozidly. V tomto článku jsou uvedeny různé metody řešení dopravních nehod aplikovatelné pro jednotlivé typy nehod a je zde vypracováno i schéma, podle kterého mohou např́klad soudní znalci postupovat při vyhodnocování dopravní nehody.

Jelikož doposud podobný návrh komplexního řešení různých typů střetů motocyklu s vozidly chyběl, mohla by být tato práce užitečnou př́ručkou s jak teoretickým, tak i praktickým využitím.

Vývojové diagramy mohou sloužit jako podklady pro soudní znalce zabývající se řešením dopravních nehod za účasti motocyklů.

\section{LITERATURA}

[1] BRADÁČ, A. a kol. Soudní inženýrství. 1. vydání, CERM, Brno, 1997, 720 s. ISBN 80-7204-057-X.

[2] SEMELA, M. Analýza silničních nehod I. 1. vydání ÚSI VUT v Brně, 2012, 83 s. ISBN 978-80-214-4559-8.

[3] SEMELA, M. Analýza silničních nehod II. 1. vydání ÚSI VUT, Brno, 2012, 35 s. ISBN 978-80-214-4560-4.

[4] RÁBEK, V. Vybrané postupy analýzy dopravních nehod. Sborník prevzatých cizojazyčných př́spěvků, EDIS Vydavatelstvo Žilinskej Univerzity, Žilina, 2009, 27 s. VPRA-SCP-2009-06-02.

[5] KASANICKÝ, G., KOHÚT, P. Analýza nehôd jednostopových vozidel. Žilinská universita v Žilině, Žilina, 2000, 201 s. ISBN 80-7100-598-3.

[6] HUGEMANN, W. Unfall rekonstruktion. 1. vydání, 2007, 771 s. ISBN 3-00-019419-3.

[7] BURG, H., MOSER, A. Handbook of accident reconstruction. 1. vydání, VIEWEG, 2014, 985 s. ISBN 978-3-8348-0172-2.

[8] Virtual Crash [počítačový program]. Dostupné z: http://www. vcrash3.com.

[9] PC Crash [počítačový program]. Dostupné z: http://www.pccrash.com.

\section{Správná citace:}

SLEPÁNEK, P. Postup při řešení střetu motocyklu se silničním motorovým vozidlem. Soudní inženýrství, 2018, 29(4), 15-24. DOI: http://dx.doi.org./10.13164/SI.2018.4.15. ISSN 1211-443X. 